\title{
Heterotrophic Succession in Carrion Arthropod Assemblages
}

\author{
Mauricio Osvaldo Moura*, Emygdio Leite de Araújo Monteiro-Filho and Claudio José \\ Barros de Carvalho \\ Departamento de Ciências Biológicas; Universidade Estadual do Centro-Oeste; C. P. 730; moura@unicentro.br \\ 85015-430; Guarapuava - PR - Brazil. Departamento de Zoologia; Universidade Federal do Paraná; C. P. \\ 19020; 81031-970; Curitiba - PR - Brazil
}

\begin{abstract}
Investigations were conducted on carrion attendant insects succession at two contrasting sites to determine if it was a discrete process or not. The visitation pattern of species revealed that saprophagous and predator species had complementary patterns of arrival and that percentage of reoccurring taxa ranged between 40 and $46 \%$, except during winter when it reached $96 \%$. The forested site always presented a higher richness than urban site, and at both the sites the tendency of species increase showed an exponential growth and then a decline. The arriving pattern was clumped in the earlier decompositional stages. At both the sites no clear boundaries were found between the decomposition stages, thus suggesting a continuous process and also suggesting that the facilitation was not the process generating the observed pattern.
\end{abstract}

Key words: Carrion Community, Facilitation, Heterotrophic Succession, Insect Succession

\section{INTRODUCTION}

Succession is one of the most important concepts in ecology but its exact definition is problematic since several phenomena fit in this term (Miles, 1987). Its theoretical background was developed mainly by F. E. Clements in his papers of 1914 and 1916 (Connel and Slatyer, 1977). In his theory, Clements proposed that the association between successional stages produces discrete boundaries which leads to an unique regional climax.

Another view of such process was proposed by $\mathrm{H}$. A. Gleason in 1917 and further detailed in his 1926 paper (McIntosh, 1995). Gleason introduced a different model to look at succession with species responding individually to a complex of biotic and abiotic forces do not showing discrete boundaries between succession stages. This leads to a continuum of change without regional climax and with several local climax (McIntosh, 1995). Presently also, this controversy is still an open question but it seems that the Clementsian view is being changed for a Gleason's "continuum" view of community structure (McIntosh, 1995). Succession in ephemeral communities has been described as a discrete process by several authors (e.g. Payne, 1965, Lane, 1975), mainly based on its utility in forensic practices although some studies have put this assertion in doubt (Schoenly and Reid, 1987). Several papers dealing with heterotrophic succession have been published (Reed, 1958, Payne, 1965, Hodge and Arthur, 1996) but

* Author for correspondence 
Schoenly and Reid (1987) were the first to focus on the dynamics of heterotrophic succession and to propose that this pattern was not discrete but continuous in the majority of cases.

The dynamics of succession in ephemeral communities is very important for medicolegal situations (Schoenly, 1992) and could have implications on a broad scale (between patch dimension) on the regional dynamics, because every carcass is a source of colonists to the regional system (Hanski, 1987).

The hypothesis of a discrete process implies that there must be more similarity in species composition within a particular phase of decomposition than between decompositional stages. This occurs due to temporal separation between groups of species attracted to a particular phase of decomposition. Alternatively, if there is no such compartments, the process cannot be described as discrete and, therefore, a continuum view should be considered. The purpose of this paper was to test whether the carrion communities herein studied exhibited a discrete or continuous succession pattern.

\section{MATERIAL AND METHODS}

The database of necrophagous community (Moura, 1996) was used in this study which comprises the sequences of carrion attendant arthropods assembled seasonally in rat carcasses. The whole database was analyzed which resulted exclusion of two samples (Autumn and Summer) from the urban site (site A). In these two samples, the dynamic of colonization imposed by Solenopsis sp. (Hymenoptera, Formicidae) turned the pattern truncated, with species being almost unable to lay eggs on carcass (see Moura et al., 1997), resulting in a assembly of few species, most of them present one or two days.

The methodology for specimens collections has been described previously by Moura et al. (1997). During 1994 and 1995 a survey of the carrion fauna was made at two sites located in the city of Curitiba $\left(25^{\circ}\right.$ $\left.25^{\prime} \mathrm{S}, 49^{\circ} 25^{\prime} \mathrm{W}\right)$, state of Paraná using standard methods (vertebrate exclusion cages). The sites were located in an urban environment (site A) and in a forest (site B). During this period, a laboratory-bred rat carcass (Rattus norvergicus) weigh $250 \mathrm{~g}$ and killed by cervical dislocation, was exposed at each of the two sites. Daily observations were made at both sites simultaneously for periods of at least 120 minutes each. In the course of these observations, larval and adult insects on the carcass were collected. In order to test for pattern on data, an occurrence matrix was created with presence/absence data entries in a matrix of species per day of decomposition. In each season for both sites the permanence time, visitation pattern and the richness were calculated. A type $\mathrm{Q}$ similarity matrix based on the occurrence matrix and calculated with Dice similarity coefficient (Pielou, 1984; Legendre et al., 1985) was used to verify the occurrence of discrete stages of change. Thereafter, a cluster analysis using UPGMA method was performed using this data. All the analyses were made running NTSYS 2.0 (Rohlf, 1998) and taxa with a single occurrence were not included. As a temporal reference to describe successional patterns the stages of decomposition that the carcass underwent were used (Reed, 1958, Moura et al., 1997).

\section{RESULTS}

\section{Visitation patterns}

Carrion attendant species has been divided in nonrecurring and reoccurring groups (Schoenly, 1992). The average percentage of reoccurring taxa was $40 \%$ at site A and $46 \%$ at site B, except in the winter when had a value of $95 \%$ (Table 1). The great majority of these species let an interval between one and two days (Table 1).

The proportion of reoccurring taxa between saprophagous and predator/parasite species did not differ, and only two species did not show discontinuity in their resource use throughout the year, Solenopsis sp. (Hymenoptera, Formicidae) at site A and Dissochaetus murray Reitter (Cholevidae, Coleoptera) at site B. 
Table 1: Seasonal modifications in the numbers of reoccurring taxa at site A and B. The asterisk indicates taxa that are twice reoccurring

\begin{tabular}{lcccccccccc}
\hline & & $\begin{array}{c}\text { Number of } \\
\text { taxa }\end{array}$ & $\begin{array}{c}\text { Number of } \\
\text { reoccurring taxa }\end{array}$ & \multicolumn{2}{c}{$\begin{array}{c}\text { Percentage of } \\
\text { reoccurring }\end{array}$} & \multicolumn{4}{c}{$\begin{array}{c}\text { Interval between } \\
\text { Occurrences (days) }\end{array}$} \\
\hline Autumn & B & 14 & $6^{*}$ & 42,8 & 4 & 1 & 2 & - & - & - \\
Winter & $\mathrm{A}$ & 9 & 6 & 66 & 2 & 2 & 2 & - & 1 & 1 \\
& $\mathrm{~B}$ & 20 & $19^{*}$ & 95 & 27 & 15 & 10 & 2 & 3 & 10 \\
\multirow{2}{*}{ Spring } & $\mathrm{A}$ & 9 & $8^{*}$ & 88,8 & 5 & 1 & 1 & 2 & - & - \\
& $\mathrm{B}$ & 14 & $7^{*}$ & 50 & 5 & 2 & - & 2 & - & - \\
Summer & $\mathrm{B}$ & 13 & $6^{*}$ & 46,1 & 7 & 1 & 1 & - & - & - \\
\hline
\end{tabular}

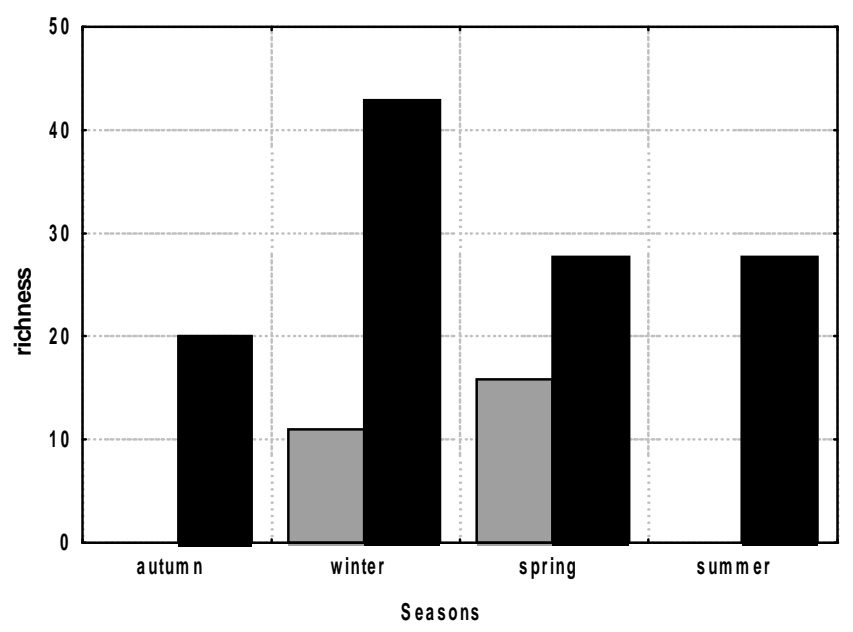

Figure 1 - Seasonal and site differences in richness of species attracted to rat carcasses. Urban site A (gray bars) and Forested site B (black bars).

The proportion of reoccurring taxa between saprophagous and predator/parasite species did not differ, and only two species did not show discontinuity in their resource use throughout the year, Solenopsis sp. (Hymenoptera, Formicidae) at site A and Dissochaetus murray Reitter (Cholevidae, Coleoptera) at site B.

There was no apparent pattern with respect to occupation time with only Solenopsis sp., Lucilia eximia (Wied.) (Diptera, Calliphoridae) and Dissochaetus murray being present more than 50\% of the time in all the seasons. All other species had an occupation time below $10 \%$. The richness differed markedly between the two sites, being greater at site B (Fig. 1). The pattern of richness increase showed an exponential growth and then a decline in species number. In general, this exponential growth presented a single peak corresponding to the decaying stage, but at both the sites there were more than one peak in the winter. The arriving pattern, on both the sites, showed that the great majority of species arrived in the fresh/bloat stage (1-5 days after placement) and that a secondary peak during the decaying stage (513 days after placement) could occur (Fig. 2). In the winter the arrival of all species showed a scattered pattern at both the sites (Fig. 2).

The saprophagous and predator/parasites successional patterns tended to be complementary during most part of the process. In general, the saprophagous species were more numerous than predator/parasites in fresh and bloat stages, that is in the beginning of process, whilst in the decaying stage the predator/parasites were more numerous. 
In the last stages (dry at site A and adipocere-like at site B) there was a difference between the sites. At site A, the predator/parasite species were more numerous than saprophagous ones. On the other hand, at site B the opposite occurred that is the saprophagous species were more numerous than predator/parasite ones.

\section{Continuous or discrete process?}

The cluster analysis showed that, in general, it was not possible to distinguish the fresh and bloat stages from each other but it was possible to distinguish the previous two stages from decaying/dry stages at site A. The last two stages did not show definite boundaries between them (Fig. 3). In all analyses it was possible to observe a transition between the stages, which means that the days which set up the stage were not grouped together into a single cluster. Moreover, there was also a clear boundary between the stages in which saprophagous were dominant from the periods of predator/parasite dominance.
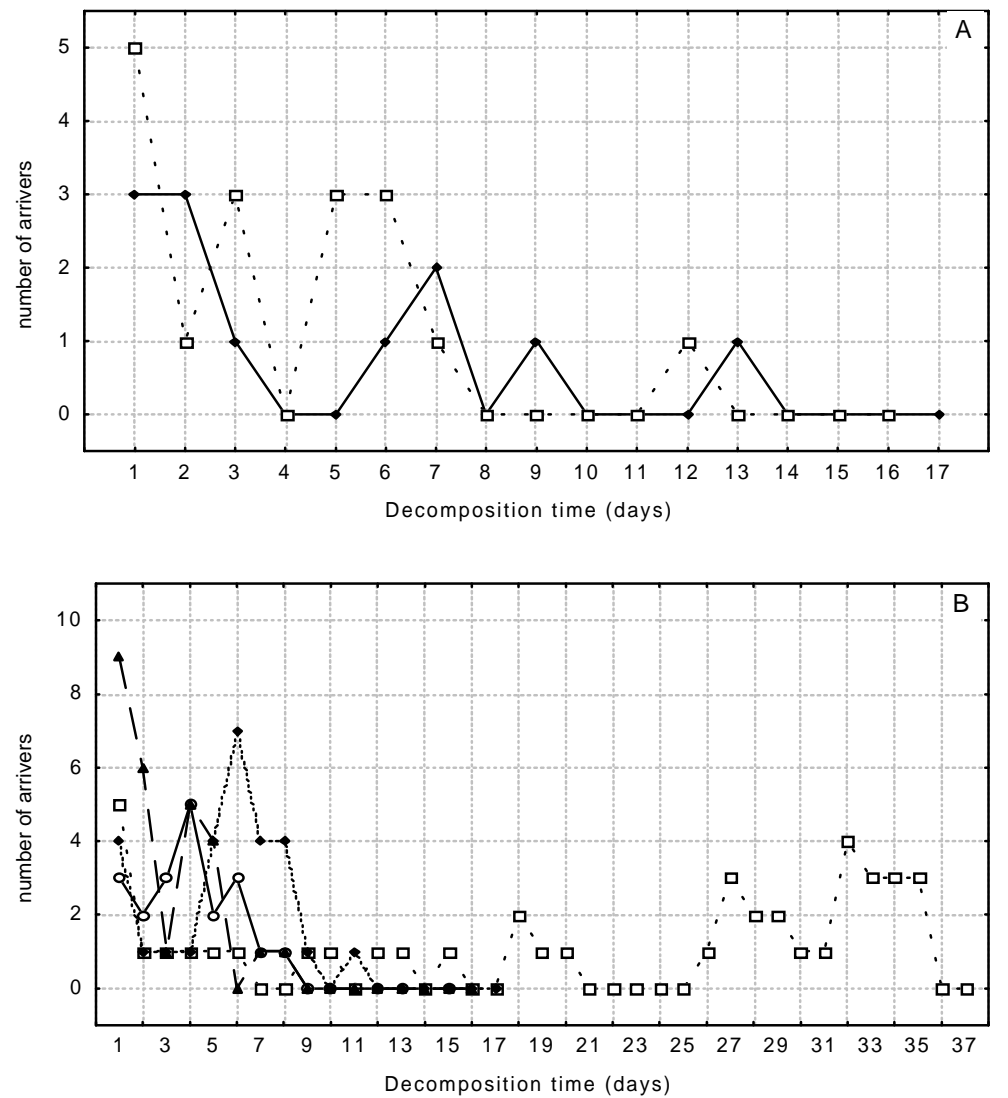

Figure 2 - Number of arriving species attracted to rat carcasses at urban (A) and forested (B) sites during decompositional process in Autumn (o), Winter ( $\square$ ), Spring ( $\bullet$ ) and Summer $(\boldsymbol{\Delta})$. 

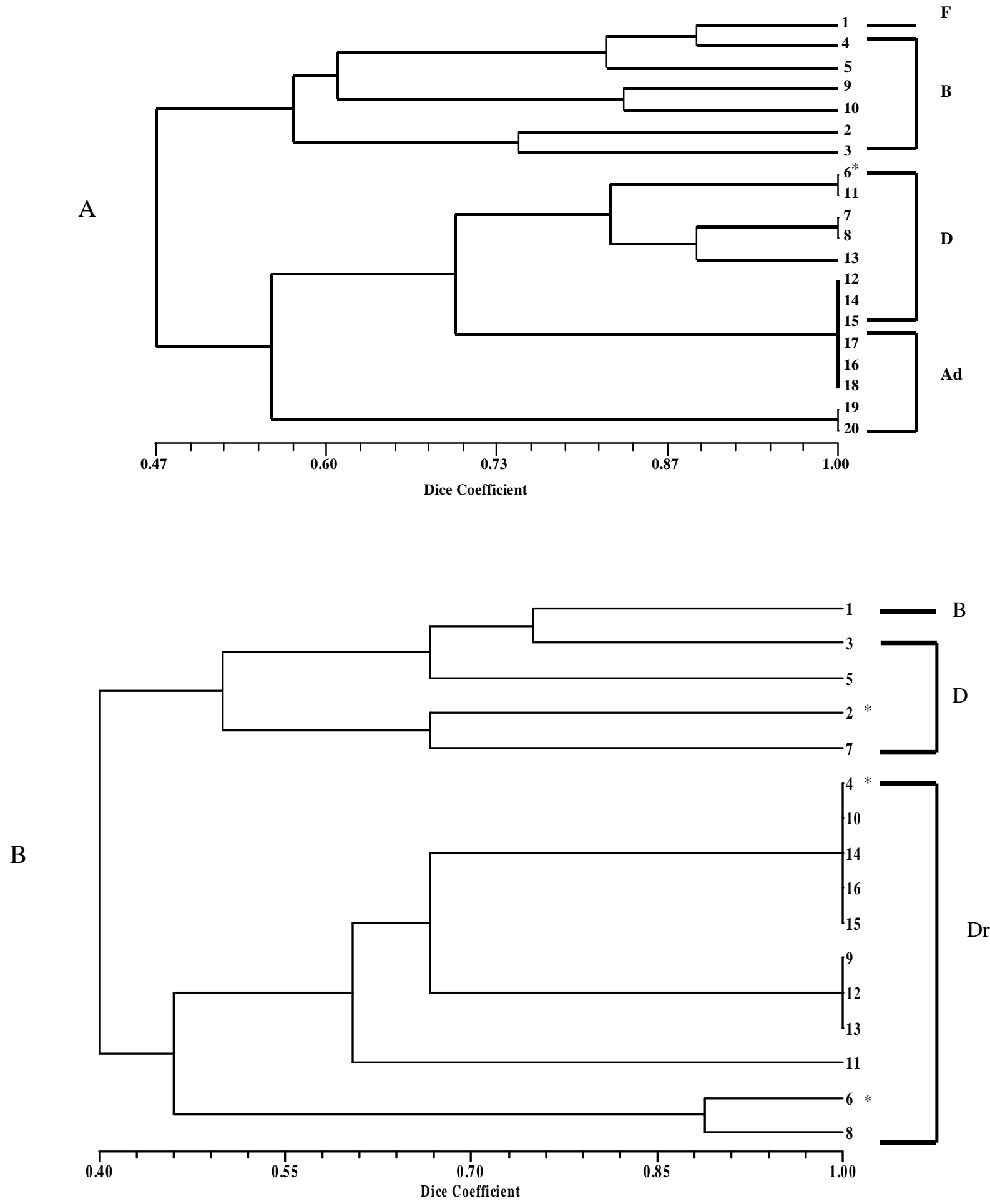

Figure 3 - Cluster analysis showing within decompositional period (in days) similarities and their relationship with decompositional stages in Winter (A) and Spring (B) at the urban site. The decomposition stages are: Fresh (F), Bloating (B), Decaying (D), Dry (Dr) and Adipocere (Ad). Transition days are symbolized by $(*)$. 


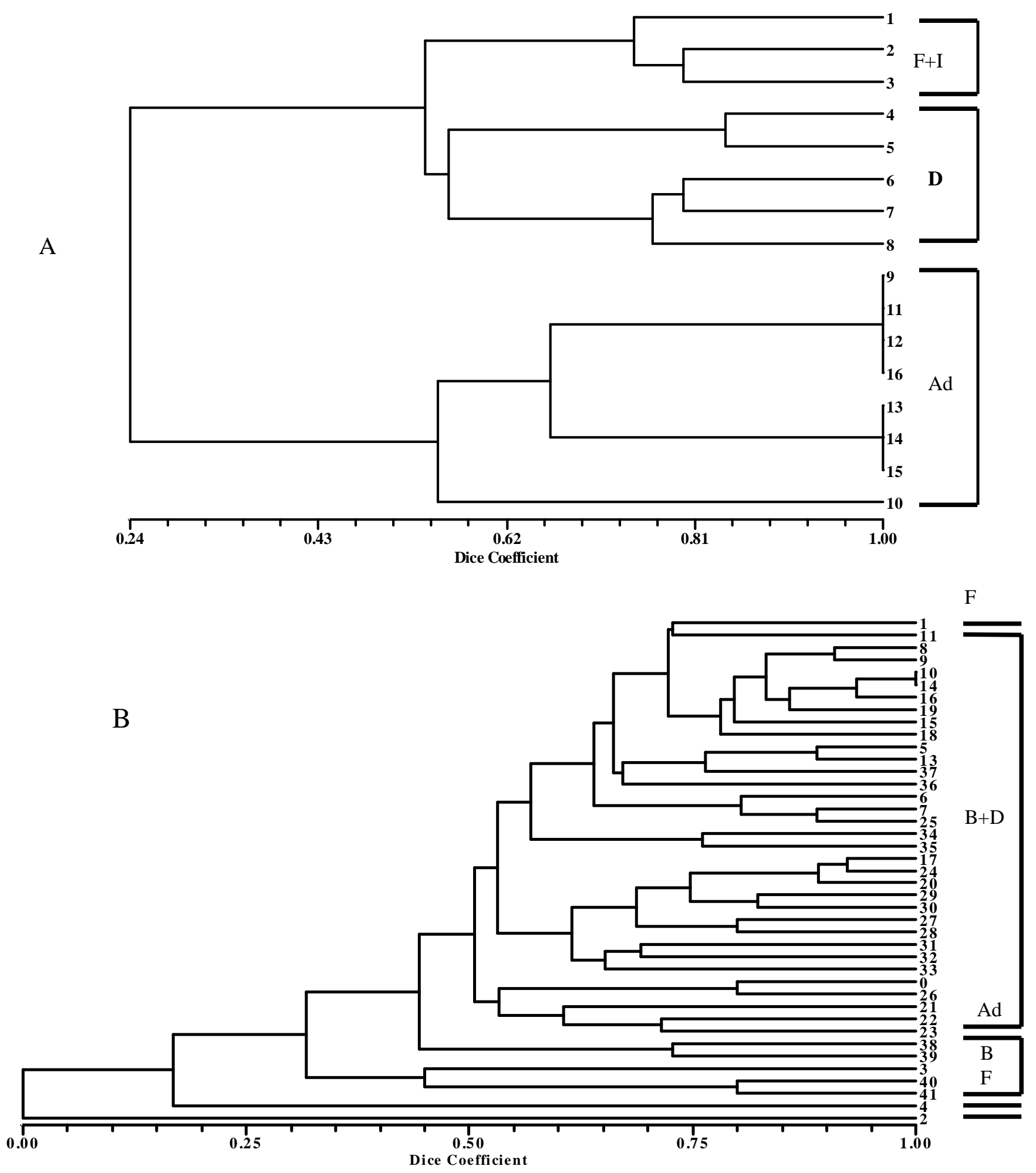

Figure 4 - Cluster analysis showing within decompositional period (in days) similarities and their relationship with decompositional stages in Autumn (A) and Winter (B) at the forested site. The decomposition stages are: Fresh (F), Bloating (B), Decaying (D) and Adipocere (Ad). Transition days are symbolized by (*). 

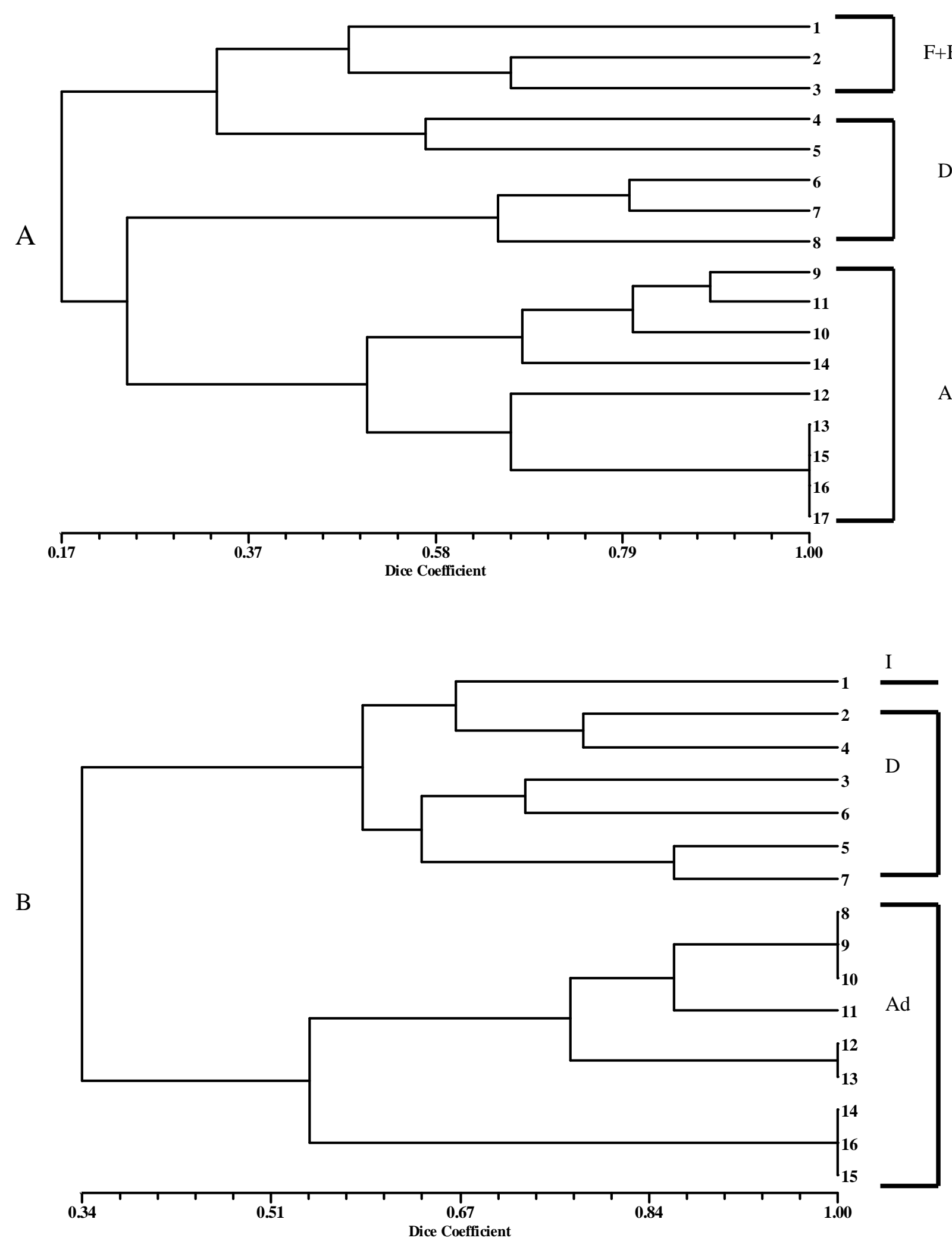

Figure 5 - Cluster analysis showing within decompositional period (in days) similarities and their relationship with decompositional stages in Spring (A) and Summer (B) at the forested site. The decomposition stages are: Fresh (F), Bloating (B), Decaying (D) and Adipocere (Ad). Transition days are symbolized by (*). 
At site B on the other hand, except for winter, it was possible to set boundaries between all stages in all seasons and, as occurred at site $\mathrm{A}$, the presence of transitional days in all clusters could be noted (Figs. 4 and 5). The analysis did not show clear boundaries between the periods in which saprophagous were dominant from the periods of predator/parasite dominance (Fig. 5).

\section{DISCUSSION}

Working with 23 studies compiled from a bibliographic survey, Schoenly (1992) found an average of $20 \%$ of reoccurring taxa, which was well below the value of $43 \%$ obtained in the present study. Some factors could be responsible for these differences such as seasonal variation, which was not included in Shoenly's work. The value also could have been underestimated because it represented an average of 23 different studies and did not consider methodological differences in field protocols. In addition, the great majority of reoccurring taxa we recorded let a single day interval, which is in agreement with Schoenly (1992) observations. The higher value of reoccurring taxa at site $\mathrm{B}$ occurred in winter as was also reported by Monteiro-Filho and Penereiro (1987), probably due to significant temperature oscillation. At site A, the Spring sample showed the higher value of reoccurring taxa, a fact that was probably linked to the colonization dynamics of Solenopsis sp.

The greater richness recorded at site $\mathrm{A}$ was in spring because there were several taxa with reduced permanence time. At site $B$, the greater richness occurred in winter because the carcass decomposes more slowly allowing a greater time for exploitation (Monteiro-Filho and Penereiro, 1987). The arrival pattern showed a clumped distribution in the early stages, which was also found by Schoenly and Reid (1987) and Schoenly (1992). This pattern had an immediate influence upon the succession concept in carcass that should be viewed more as a species addition process than a species replacement as previously observed by Braack (1987).

The question whether the succession process was continuous or discrete in ephemeral communities was also considered by Schoenly and Reid (1987).
These authors, working with 11 compiled studies found in the majority of the cases that the process was continuous and just a few could be considered discrete ones. Our findings also suggested the process should be continuous, since no clear discrete steps could be identified.

This result could be analyzed in two ways: the process on the carcass and the process inside the carcass. For the species using the substratum for feeding (fluid-feeders), the changes a carcass undergoes is a proteic gradient. In such a gradient the resource is low at the beginning becoming higher in the middle and the declining until the end of the process, exactly as a species over time curve. On this pattern, it is very difficult to find out discrete successional stages and consequently the continuum concept remains as the most powerful descriptor for such process.

Alternatively, for species that breed on the carcass and for their larvae, utilization patterns can be recognized (Schoenly, 1992; Souza and Linhares, 1997; Moura et al., 1997); this is probably the reason that leads several researchers to consider the process as a discrete one. The conclusion that some species are associated with decompositional stages does not conflict with the fact that the process is continuous. In fact, these associations are just a by-product of observation to recognize and classify a pattern and not the description of a phenomenon. Moreover, the time the larvae spent inside the carcass largely overlaps (Payne, 1965; Braack, 1987; Moura et al., 1997), do not demonstrating temporal separation, which also suggests a continuous process.

The conclusion that the succession in carcass represented a continuous process was contrary to the largely accepted facilitation process of succession (Connell and Slatyer, 1977; Braack, 1987; Hanski, 1987; Schoenly and Reid, 1987), because this concept is based upon Clements concepts of succession, under which the communities were understood as discrete (McIntosh, 1995).

In conclusion, no discrete boundarie between waves of arrivers attracted to a small carcass at two contrasting sites in Southern Brazil.were found. These findings as well as the results obtained by Schoenly and Reid (1987) seemed to point towards a continuous approach of successional process on carcass. 


\section{ACKNOWLEDGEMENTS}

We are grateful to Silvio Nihei, Juliana Quadros, Arício X. Linhares and Marcio R. Pie for comments on the manuscript. This research was supported by grants from Conselho Nacional de Pesquisa e Desenvolvimento Científico e Tecnológico - CNPq.

\section{RESUMO}

A Sucessão ecológica em comunidades efêmeras tem sido tratada como um processo discreto por vários autores, mesmo em detrimento de algumas evidências que apontam para um processo contínuo. Esta controvérsia aparentemente deve-se ao uso forense dos dados de sucessão. Baseado nestes fatos, nós analisamos dados da sucessão de insetos sobre carcaças em dois locais contrastantes fisionomicamente para determinar a natureza do processo de sucessão: se discreto ou contínuo. Os padrões de visitação demostraram uma complementaridade no padrão de chegada entre espécies saprófagas e predadoras e que a taxa de recorrentes variou entre $40 \%$ e $46 \%$ com exceção do inverno com valores próximos a 95\%. A área florestada sempre apresentou maior riqueza que a área urbana e, em ambas as áreas, a tendência ao aumento da riqueza seguiu um padrão exponencial com um declínio posterior. O padrão de chegada indica uma agregação de espécies nos primeiros estágios de decomposição. Em ambas as áreas não foram encontradas separações claras entre as fases que compõem o processo de decomposição, sugerindo assim, um processo contínuo e sugerindo também, que a facilitação não é o processo que estaria gerando o padrão observado.

\section{REFERENCES}

Braack, L. E. O. (1987), Community dynamics of carrion-attendant arthropods in tropical african woodland. Oecologia (Berlin), 72, 402-409.

Connell, J. H. and Slatyer, R. O. (1977), Mechanisms of succession in natural communities and their role in community stability and organization. Am. Nat., 111, 1119-1144.

Hanski, I. (1987). Colonization of ephemeral habitats In: Gray, A. J.; Crawley, M. J. and Edwards, P. J. (Eds.). Colonization, Sucession and Stability. London : Blackwell Scientific Publications. pp. 155185.

Hodge, S. and Arthur. W. (1996), Insect invasion sequences: systematic or stochastic? Ecol. Entomol., 21, 150-154.

Lane, R. P. (1975), An investigation into Blowfly (Diptera: Calliphoridae) succession on corpses. $J$. Nat. Hist., 9, 581-588.

Legendre, P., Dallot, S.and Legendre, L. (1985), Succession of species within a community: Chronological clustering, with applications to marine and freshwater zooplankton. Am. Nat., 125, 257-288.

McIntosh, R. P. (1995), H. .A. Gleason's individualistic concept and theory of animal communities: a continuing of controversy. Biol. Rev., 70, 317-357.

Miles, P. (1987), Vegetation succession: Past and present perceptions. In: Gray, A. J.; Crawley, M. J. and Edwards, P. J. (Eds.). Colonization, Sucession and Stability. London : Blackwell Scientific Publications. pp. 81-102.

Monteiro-Filho, E. L. A. and Penereiro, J. L. (1987), Estudo de Decomposição e Sucessão sobre uma carcaça animal numa área do Estado de São Paulo, Brasil. Rev. Bras. Biol., 47, 289-295.

Moura, M. O. (1996), Decomposição, sucessão e faunística:Uma análise comparativa entre dois ambientes. M.Sc. thesis, Universidade Federal do Paraná, Curitiba, Brasil.

Moura, M. O., Carvalho, C. J. B. and Monteiro-Filho, E. L. A. (1997), A preliminary analysis of insects of medico-legal importance in Curitiba, State of Paraná. Mem. Inst. Oswaldo Cruz, 92, 269-274.

Payne, J. A. (1965), A Summer Carrion Study of the baby Pig Sus scrofa Linnaeus. Ecology, 46, 591-602.

Pielou, E. C. (1984), The interpretation of ecological data: A primer on classification and ordination. John Wiley and Sons, N.Y. 
Reed, H. B. (1958), A study of dog carcasses communities in Tenessee, with the special reference to the insects. Am. Mid. Nat., 59, 213-245.

Rohlf, F. J. (1998), NTSYS-pc, Numerical taxonomy and multivariate analysis system, version 2.0. Exeter software, N.Y.

Schoenly, K. (1992), A statistical analysis of sucessional patterns in carrion-arthropod assemblages: Implications for forensic entomology and determination of the postmortem interval. JFSCA, 37, 1489-1513.

Schoenly, K. and Reid, W. (1987), Dynamics of heterotrophic succession in carrion arthropod assemblages: discrete series or a continuum of change? Oecologia (Berlin), 73, 192-202.

Souza, A. M. and Linhares, A. X. (1997), Diptera and Coleoptera of potential forensic importance in Southeastern Brazil: relative abundance and seasonality. Med. Vet. Entomol., 11, 8-12. 